\title{
PHD Theses - Thèses de doctorat - Doktorarbeiten
}

If you are about to complete or have recently completed a $\mathrm{PhD}$ in European integration history or a related field, and would like to see your abstract published here, please contact:

Si vous êtes sur le point de terminer une thèse de doctorat en histoire de l'intégration européenne ou dans une discipline proche et vous voulez publier un abstract de votre travail, contactez:

Falls Sie ihr Doktorat im Bereich der europäischen Integrationsgeschichte oder einer ihr nahestehenden Disziplin abgeschlossen haben oder demnächst abschließen und eine Kurzfassung ihrer Arbeit veröffentlichen möchten, melden Sie sich bei:

Guia Migani:

guia.migani@univ-tours.fr
Katja Seidel:

k.seidel@westminster.ac.uk

Hélène CAUNE, Les États providence sont aussi des États membres. Comparaison des logiques nationales de l'européanisation des politiques de l'emploi en France et au Portugal [European Welfare states as Member States. Comparing the National Logics of Europeanization in the Employment Policy Field in France and Portugal] - SciencesPo, Paris

Supervisor/jury: Nicolas JABKO, Johns Hopkins University (directeur de thèse); Patrick HASSENTEUFEL, Université de Versailles Saint-Quentin-en-Yvelines; Claudio M. RADAELLI, University of Exeter; Sabine SAURUGGER, Institut d'Études Politiques de Grenoble; Cornelia WOLL, Institut d'Études Politiques de Paris

Domaine: sciences politiques

Date de la soutenance: 13.12 .2013

Contact: helene.caune@sciences-po.org

La littérature académique sur les politiques de l'emploi a tendance à se concentrer sur les variables nationales du changement. Cette thèse s'intéresse à la perméabilité des frontières nationales de l'action publique dans un contexte européanisé et adopte une approche interactionniste de l'européanisation. Elle repose sur une analyse qualitative de la littérature grise produite par les institutions et les acteurs engagés dans les réformes des politiques de l'emploi et sur 87 entretiens semi-directifs conduits avec ces acteurs. Une observation participante de deux mois auprès du Secrétariat général de la Commission européenne a également été menée.

Ce travail revient d'abord sur le développement de l'intégration européenne dans le domaine des politiques de l'emploi, une étape qui donne un cadre historique pour analyser la longue construction politique du modèle qui nous intéresse, celui de la flexicurité. Défini au cours des années 2000, ce néologisme articule deux dimensions 
que les experts et les acteurs politiques ont longtemps considérées comme incompatibles : flexibilité des marchés du travail et sécurité des travailleurs. Prenant en considération la période qui va de 1957 jusqu'aux premiers moments de la gestion de la crise financière et économique à la fin des années 2010, la thèse souligne les moments et les acteurs clés de la construction de ce modèle dont les axes se développent parallèlement depuis la signature du Traité de Rome, mais ne se rencontrent qu'au cours des années 2000.

La thèse se penche ensuite sur la comparaison de deux cas nationaux. Elle revient sur les fondements historiques des systèmes de protection sociale français et portugais, des systèmes longtemps éloignés des cadres de la flexicurité, mais qui connaissent désormais des réformes allant dans le sens prescrit par les institutions européennes. Dans ce cas, la période analysée commence dans les années 1990, marquées par les perspectives de l'adoption de la monnaie unique, et couvre les réformes les plus récentes des politiques du marché du travail, en 2012 au Portugal et en 2013 en France.

Les chapitres nationaux interrogent le rapport entre la construction singulière des politiques de l'emploi françaises et portugaises dans un contexte européen. Ici, la recherche souligne deux phénomènes particuliers. Il s'agit d'abord de l'inscription des sphères sociales nationales dans un contexte européen peu pris en compte dans les travaux sur l'État providence alors même qu'il met les Etats en concurrence les uns avec les autres. Il s'agit ensuite de la structure de la représentation syndicale, un facteur qui influence la capacité des syndicats français et portugais à participer au recadrage national des orientations européennes. In fine, la thèse montre que si les frontières sociales nationales n'ont pas disparu, elles sont largement remises en cause par l'intégration européenne.

Ali MOURAD, Les transformations des relations euro-méditerranéennes après le cinquième élargissement de l'UE : Portée et limites des cadres de voisinage euroméditerranéens - Université de Rennes I et Université Libanaise JURY: Catherine FLAESCH-MOUGIN, Université de Rennes I, Chaire européenne Jean Monnet (codirecteur); Georges SAAD, Université Libanaise (codirecteur); Erwan LANNON, Université de Gand; Joël LEBULLENGER, Université de Rennes I, Chaire européenne Jean Monnet; Rami SAYADI, Université Libanaise

Domaine: droit

Date de la soutenance: 28.03 .2014

CONTACT: mouradali1@hotmail.com

La construction de la CE/UE et l'enracinement des liens avec les Pays Tiers Méditerranéens (PTM) épousent des logiques distinctes. Leurs objectifs, mécanismes et outils sont différents: l'un relevant de l'ordre interne, l'autre externe. Pourtant, une analyse historique montre qu'à chaque stade de l'élargissement, les relations avec les PTM en sont sorties bel et bien raffermies. L'évolution communautaire pose la question de l'équilibre interne entre les États membres et l'UE où le potentiel de devenir un acteur politique sur la scène internationale s'accentue. $\mathrm{Si}$, au départ, ces relations 
sont de nature économique, dans un cadre essentiellement bilatéral, les bouleversements politiques des années 1990 les modifient en leur conférant une nouvelle dimension. L'UE réaffirme l'importance stratégique accordée à ses partenaires de la Méditerranée; d'où, en 1995, la naissance du Partenariat euro-méditerranéen (PEM) qui représente une évolution historique notable de ces relations. Avec la mise en place d'un cadre multilatéral complété par la conclusion des accords d'association, ce Partenariat représente une rupture avec les politiques méditerranéennes antérieures.

Plus tard, dans le contexte du cinquième élargissement de l'Union européenne du 1er mai 2004, la Politique Européenne de Voisinage (PEV) transforme le PEM en préconisant la création d'un cercle d'amis avec les voisins méditerranéens du Sud et les nouveaux voisins de l'Est. Ces transformations des relations euro-méditerranéennes ont permis l'émergence progressive d'une nouvelle forme relationnelle. Ce métissage est le résultat de la rencontre entre deux cadres à objectifs différents et contextes géostratégiques différents : le PEM comme cadre de coopération régionale établi dans les années 1990 et une PEV en tant que politique de l'UE employant les méthodologies issues du processus de préadhésion.

Cette thèse définit le résultat de cette nouvelle dynamique interactive des politiques de l'UE sous le nom de cadres de voisinage euro-méditerranéens. La délimitation de ces cadres passe par l'analyse des transformations des relations après le cinquième élargissement en distinguant la dimension multilatérale de la dimension bilatérale. Cet impact contrasté sur les deux dimensions change l'approche de la coopération euro-méditerranéenne ouvrant la porte à un éventuel dépassement progressif du cadre en place au profit d'une approche globale de voisinage à long terme. Ces cadres deviennent le résultat de la convergence entre une relance euro-méditerranéenne multilatérale en dehors de la PEV qui est restée dans la continuité de la pratique barcelonaise, d'une part, et le renforcement essentiellement bilatéral par la PEV, d'autre part. En se basant sur des sources telles que les accords d'association, les plans d'actions adoptés avec chacun des voisins, les communications de la Commission sur la PEV et sur une doctrine juridique et économique, cette étude qui retrace une évolution historique du développement des relations de la CEE/UE avec les Pays tiers méditerranéens, se focalise sur la période de 2003 à 2012 avec une attention particulière portée à la nouvelle donne du «Printemps arabe» qui impose une redéfinition stratégique des relations de l'UE avec la Méditerranée. 
Christian SALM, Transnational Socialist Networks in the 1970s: The Cases of European Community Development Aid and Southern Enlargement - University of Portsmouth

Supervisor/Jury: Wolfram KAISER, University of Portsmouth (supervisor); Brigitte LEUCHT, University of Copenhagen; Jan-Henrik MEYER, Aarhus University; Stefan BERGER, Institute for Social Movements/Ruhr-University Bochum; David HANLEY, University of Portsmouth

Field: history

Date of the exam: 08.10 .2013

Contact: christian.salm@port.ac.uk

This thesis examines the role of the Western European socialist parties' transnational cooperation in European integration in the 1970s. It argues that their cooperation across national borders significantly influenced politics and policy-making in what was then the European Communities (EC). The thesis focuses on the network-like informal structures that characterised transnational cooperation between those socialist (leading) party members/leaders of different national parties involved in European affairs. Methodologically, the study draws on concepts from political science, notably, the 'policy network' approach and the notion of 'Europeanisation' and utilises these concepts as analytical tools for historical source analysis. Empirically, the study is based on extensive archival research in 17 archives in nine countries, including newly accessible party sources and previously undisclosed private papers. While so far research concentrated on Christian democrats' contribution to European integration, for the first time, the thesis documents that socialist transnational cooperation in and through transnational networks was an important factor of the emerging European governance system.

In two case studies, the thesis addresses the role of the socialist transnational cooperation concerning two important policy areas, namely, EC development aid policy and EC Southern enlargement policy. Both policy fields helped define the external dimension of European politics and policy-making in the 1970s with major challenges such as the fair distribution of resources between the rich North and the poor South and the transitions in Southern Europe with tremendous consequences for the political order in Western Europe and the EC. The thesis demonstrates that the socialist parties strengthened their informal transnational network structures for the purposes of debating ideological and programmatic issues and finding policy solutions to common challenges in both policy fields. Moreover, it shows that the socialist transnational networks developed various functions to influence European governance. Against this background, the analysis in this thesis makes not only a significant contribution to the study of transnational networks of western European socialist parties and European integration in the 1970s; it also adds to our understanding of the role of transnational networks in European politics and policy-making. 
Beatrice SCUTARU, Les relations entre les sociétés française et roumaine des années 1960 à 1995: un atout de l'ancrage de la Roumanie à l'Europe? [Relations between French and Romanian Societies from the 1960s to 1995: an Asset Linking Romania to Europe?] - Université d'Angers (France)

Jury: Éric BUSSIÈRE, University of Paris IV; Adrian CIOROIANU, University of Bucarest; Yves DENÉCHÈRE, University of Angers (Supervisor); Christine MANIGAND, University of Paris III, Alexandru-Florin PLATON, University of Iasi (codirecteur de thèse); Antonio VARSORI, University of Padoua

Field: history

Date of the exam: 18.09.2013

contact: scutaru_beatrice@hotmail.com

In 2007, after a long and tortuous journey that began in December 1989, Romania became a member of the European Union. This doctoral thesis argues that enduring relationships between French and Romanian citizens played a key role in facilitating Romania's integration into the European community. By combining micro and macro-scale analysis and different historiographical fields, it also highlights the diversity and complexity that characterized these relationships from the 1960s to 1995 .

This study also assesses that relations between French and Romanian societies were highly dependent, at least until 1989, on the vicissitudes of diplomatic bilateral relations. Owing to the nature of the Romanian regime, all major policy decisions required prior approval at the highest level of government. Despite this situation, numerous case studies illustrate the intensity of personal interactions and exchanges between French and Romanian peoples: exchange programs, scientific cooperation, town twinning, technology transfer, humanitarian aid, etc. Bridges that had been destroyed immediately after the Second World War were partially rebuilt.

The fall of the Iron Curtain and the communist regimes freed French and Romanian citizens from state control and surveillance and allowed their relationships to flourish. Several projects were implemented and conducted by civil society - Opération Villages Roumains, Médecins sans Frontières etc. - both at a national and local level. These actions were aimed, for example, at helping Romanian farmers to adjust to the constraints related to European agriculture and/or market economy. Others supported and guided several structural reforms adopted by Romania in the education and childcare system. Thus, relations between French and Romanian peoples played a crucial role in Romania's Europeanization process.

This study draws upon various Romanian and French archival sources, from official documents of the Ministry of Foreign Affairs or the Romanian Communist Party to oral interviews with the main actors and stakeholders at the local and regional levels. 
